\title{
Success and limitations in the prevention of violence: a case study of nine Brazilian experiences
}

\author{
Êxitos e limites na prevenção da violência: \\ estudo de caso de nove experiências brasileiras
}

\section{Romeu Gomes 1}

Maria Cecília de Souza Minayo 2

Simone Gonçalves de Assis 2

Kathie Njaine 3

Miriam Schenker 4

\footnotetext{
1 Departamento de Ensino,

Figueira, Fiocruz.

Av. Rui Barbosa 716,

Flamengo, 22250-020,

Rio de Janeiro RJ.

romeu@iff.fiocruz.br

2 Claves, ENSP, Fiocruz.

3 Claves, ENSP,

Fiocruz; Uniplac.

4 Claves, ENSP,

Fiocruz; Uerj.
}

Abstract The present study analyzes the success of Brazilian experiences engaged in prevention of violence as well as their limitations, and seeks to show ways for a solution of the problem. The investigation underlying this article consisted in a case study of nine experiences, using triangulation of methods. For this purpose, we used questionnaires and interviewed individuals and groups. Successful results were mainly: informed citizenship, work preparation, involvement of children and adolescents in recreating and educative activities, and increased self-esteem of the children and teens involved in the experiences. The greatest difficulties found were the lack of funds and of articulation of proposals with other groups and institutions. These experiences are not the only successful ones carried out in the country, but they point to a new horizon by innovating and creating a different practical approach to violence.

Key words Prevention, Violence, Successful experiences
Resumo O presente estudo tem como objetivo analisar os êxitos e os limites de experiências nacionais na prevenção da violência e indicar possibilidades de enfrentamento do problema. A pesquisa que dá origem ao artigo consistiu num estudo de caso de nove experiências, seguindo princípios da triangulação de métodos. Foram aplicados questionários quantitativos e realizadas entrevistas (individuais e em grupo). Os resultados apontam que os principais êxitos relatados são: informação para a cidadania; preparação para o trabalho; envolvimento de crianças e adolescentes em atividades lúdicas e educativas; $e$ o fortalecimento da auto-estima dos jovens e crianças participantes. As maiores dificuldades das experiências são a manutenção financeira e a articulação de suas propostas com as de outros grupos e instituições. O estudo leva a concluir que essas experiências, ainda que não sejam as únicas bem-sucedidas no país, apontam para um horizonte novo pela forma como atuam, inovando e criando uma práxis diferenciada na abordagem da violência.

Palavras-chave Prevenção, Violência, Experiências exitosas 


\section{Introduction}

This study belongs to the field of sociopolitical studies, no matter by whom these are conducted - the government, the private enterprise or organizations of the civil society -, anchored in the directives of the Organic Law for Social Assistance created by the Constitution of $1988^{1}$. As we will see, although their basic goal is to prevent violence, all experiences related here are aimed in the first place at increasing and improving the capacity of the involved individuals to include themselves in the country's social conquests, making use of their rights and taking over their duties. The intent of the Ministry of Health when proposing an assessment of successful experiences in the prevention of violence against adolescents and children was exactly social inclusion and the conquest of rights, constituting the basis of the National Policy for the Reduction of Accidents and Violence (Ministry of Health, 2001) and the promotion of health and quality of life. In "Is it possible to prevent violence?", Minayo \& Sou$\mathrm{za}^{2}$ already addressed this issue by showing the opposite of violence not to be nonviolence but the conquest of citizenship, ensuring dialogue and understanding. As refers to the field of health, some important directives in this sense are being followed, some of them making part of the National Plan for the Prevention of Violence and of the Program for Reduction of Morbidity and Mortality from Accidents, both under the responsibility of the Secretariat for Health Control of the Ministry of Health.

The interest of the Brazilian government and of the society in proposing programs directed to social inclusion and evaluating their effectiveness is reinforced by experiences of recognized success in other countries $3,4,5,6$.

The pioneers in offering services directed to the prevention of violence however are nongovernmental organizations (NGOs) much more that the state: the Centers against Abuse and Violence (Centros Regionais de Atenção aos Maus Tratos na Infância - CRAMI), in São Paulo, the Multiprofessional Association for the Protection of Children and Adolescents (Associação Brasileira Multiprofissional de Proteção à Infância e à Adolescência - ABRAPIA), in Rio de Janeiro, and the Brazilian Association for the Prevention against Abuse and Negligence in Childhood (Associação Brasileira de Prevenção aos Abusos e Negligências na Infância - ABNAPI), in Minas Gerais, for example, played a fundamental role in the elaboration of the Statute of the Child and the Adolescent of 1990, and in the recognition of this group of citizens as subject of rights ${ }^{2}$. After this Statute, during the last 15 years, a great number of nongovernmental organizations and private societies were established and help, since then, to find mechanisms for improving the social growth and development of children and adolescents, in other words, to prevent violence against them. Some academic institutions also play a basic role in this question by training professionals, giving technical advice, analyzing programs and services and by creating assessment indicators.

The dynamism of the great number of existing proposals apart, public and private institutions and NGOs engaged with the issue "prevention of violence" pay not too much attention to a systemization of their ideas and actions. In Brazil, in general, the efforts of the health area (public and other) are much more focused on the victims of offenses than on the positive aspects representing the opposite of violence.

It is therefore extremely important to investigate the actions of institutions deliberately engaged in the prevention of violence against children and adolescents in Brazil, especially in a moment when the National Plan for the Prevention of Violence really started to be put in practice by the Ministry of Health, and when the Network of Centers for the Prevention of Violence and Health Promotion is being implemented in different states and cities with high mortality rates from external causes. A better understanding of the actions in course, the dynamics of relations and results of activities is imperative for a more efficient orientation of future steps by institutions and the government, who need instruments of intelligence for directing funds. In this case, the abundance of specificities and the coincidence of goals will indicate the multiple possibilities of action.

This is the perspective from which the present study seeks to analyze the success and the limitations of national experiences in the prevention of violence and to indicate possible solutions for the problem.

\section{Method}

The present study is based on an investigation on the prevention of violence cleared by the 
ethics committee for research involving human subjects of the National School of Public Health (ENSP/Fiocruz), in cooperation with the Secretariat for Health Control of the Ministry of Health. The study was conducted as a case study 7 . It aims to understand the different experiences of networks, programs, activities and projects (here generically called experiences), with respect to the prevention of the different manifestations of violence committed against children and adolescents, young adults and families, for detecting trends, strategies and attitudes considered successful.

In this article we will focus only the success and the limitations of these experiences, above all on the basis of qualitative data, although in the investigation that originated this paper we analyzed questionnaires using triangulation of methods, understood as an articulation between different techniques, observers and methods 8,9 . Part of the information contained in the questionnaires was used only for a general characterization of the experiences.

The experiences were selected using the following sources: 1) national surveys on preventive services against violence, for example the report of the National Department of Public Security 10 ; 2) data of the National Council for the Rights of Children and Adolescents; 3 ) news of the Agency for Children's Rights.

From the qualitative viewpoint, we conducted group interviews (focal group) with technicians of the teams providing assistance on behalf of the institution and individual interviews with coordinators (here called managers) and users, approaching mainly the following topics: purpose, methodology and service routine, forms of involvement of users, indicators for successful services, positive and negative points of the experience and articulations with the network for the protection of children, adolescents, young adults and their families. We also used field observations, but the data obtained from this process were not specifically analyzed. They were only used for contextualizing the testimonies.

The data were analyzed by means of interpretation of sense, based on hermeneutic/dialectic principles for analyzing context, reasons and logics of speech, actions and interrelations, groups, institutions, situations, among other analytical indicators ${ }^{11}$. The analysis was based on a comprehensive and contextualized interpretation of the underlying sense.
"Success and limitations" were submitted to a special treatment, using qualitative indicators created on the basis of testimonies. For analyzing the qualitative indicators we proceeded according to Gomes et al.11 and Assis et al.12, as there are: 1) comprehensive analysis of testimonies; 2) division into two classes: success or limitations/difficulties; 3 ) identification of the different senses attributed to each class; 4) unification of the senses found in each class; and 5 ) elaboration of a synthetic interpretation of indicators.

\section{Characterization of the experiences}

We studied the following experiences: 1) UgaUga Agency, Manaus (North of the country); 2) Black Culture Center, São Luís (Northeast); 3) Movement for Mental Health, Fortaleza (Northeast); 4) Sentinel Program, Cuiabá (Central West); 5) Circus for All, Belo Horizonte (Southeast); 6) Fight for Peace, Rio de Janeiro (Southeast - Rio 1); 7) Building Peace/Eduardo Guimarães College, Rio de Janeiro (Southeast - Rio 2); 8) Reference Center for Victims of Violence of the Institute Sedes Sapientiae, São Paulo (Southeast); 9) Social Center Marista, Porto Alegre (South).

The experiences Uga-Uga, Black Culture Center, Movement for Mental Health, Circus for All and Building Peace are nongovernmental organizations; the Reference Center for Victims of Violence and the Social Center Marista are foundations of private entities; and the Sentinel Program is an initiative of city authorities. The number of NGOs (six in total) demonstrates how much this group advanced in the prevention of violence in the stage of life in question. All experiences started between 1991 and 2002, with exception to the Center for Black Culture in São Luis (Maranhão), whose activities started in 1979.

The Uga-Uga Agency (Agência Uga-Uga), seated in Manaus (AM), is engaged in the prevention of sexual violence against children and juveniles through communication and transmission of information in the written and spoken media. It comprises the journal Uga-Uga, aimed at participation and protagonism of adolescents and young people, the major part of them secondary school students; the Citizen School, using communication and information in a more structured form as a teaching tool; and the ANDI Network (National Agency for 
the Rights of Childhood - ANDI), whose target public are journalists and communicators. This network aims to universalize information around questions related to childhood and adolescence.

The Center for Black Culture (Centro de Cultura Negra - CCN) in São Luis (MA) represents the first black movement in Maranhão. The center aims to educate and inform the black population about how to overcome the violent situation they are living (racial discrimination). It develops its activities in the "quilombos", intervening in the question of the ownership of the lands occupied by the communities and revising the precarious public policies being implemented. In the city, the strategy employed by the Center is to attract the attention of people with presentations of a group of dancers and percussion and educative activities. Finally, the center also gives support to school education for children between seven and thirteen years.

The Movement for Mental Health (Movimento de Saúde Mental - MSM) in Fortaleza (CE), involves in one of its centers children and adolescents in recreating activities with the aim to increase their self-esteem, and promotes professionalizing courses, especially for adolescents. The movement also involves the families through community therapy, where groups learn to listen to the problems of the neighbor and to respect them. The activities of the movement include mobilizations in schools, in the familiar environment and in church, independently from race, color, creed or ideology.

The Sentinel Program (Programa Sentinela - PS), situated in Cuiabá (MS), provides assistance to victimized children and adolescents but works also with other kinds of prevention. Today, the major part of its public is constituted by victims of sexual abuse and exploitation. The program coordinates a committee with other five organizations, aimed at mobilizing, elucidating and promoting the understanding of the nature of violence, besides indicating available services. Children and juveniles entering the program are given assistance by a multidisciplinary group, carrying out activities ranging from individual care to workshops. The actions of the program also involve family support, domestic visits and contacts with schools.

The Circus for All (Circo de Todo Mundo), situated in Belo Horizonte (MG), is the first experience making part of a project focusing sex- ual abuse of children and adolescents. The Circus works based on an attitude of permanent listening to children and adolescents living a situation of social exclusion: the street children and adolescents. The experience established joking, playing and artistic activities - theater, clay modeling and painting - as a pedagogic tool for discussing violence. It also acts at schools and in the families, as refers to the latter aiming at making parents aware of their role in the education of their children, a task often delegated to the professionals of the Circus.

The NGO Fight for Peace (Luta pela Paz) is situated in the slum called Complexo da Maré, in Rio de Janeiro (RJ). Its main proposal is to offer boxing as contact sport with the young, who live in a community, deeply affected by drug abuse and armed urban violence. The users have to frequent lessons about citizenship as a prerequisite for participating in the modalities freestyle, boxing and capoeira. There are also lessons about prevention, mainly with regard to sexually transmitted diseases - AIDS included - and abortion. The experience counts on the cooperation of a number of companies introducing these young people to the labor market.

The experience Construction of Peace (Construção da $\mathrm{Paz}-\mathrm{CP}$ ) is a recent program promoted by a private school existing for decades, with seat in the city of Rio e Janeiro (RJ). Its proposal is to form constructors of peace by means of actions that contemplate the gestalt of the individual, its relations and interrelations, aiming to motivate a better social conduct. This experience is aimed at involving parents, teachers and the community in general in actions involving care and creating awareness with respect to the inclusion of individuals with special needs in the school environment. It intends to sensitize society with regard to differences, promote solidarity among the participants and discussions about values and ethics, and fosters voluntary actions among all involved persons.

The Reference Center for Victims of Violence (Centro de Referência às Vítimas de Violência - CRVV) is one of the four centers composing the Sedes Sapientiae Institute in São Paulo. Its goal is to train professionals, parents, children and adolescents of a certain institution situated in a problematic region, in the prevention of violence, especially domestic violence. The institution is then transformed into a pole for prevention, a multiplier of ideas and 
actions. The capacity-building process is based on a participative methodology with the final goal of creating references for multipliers in this institution.

The Social Center Marista (Centro Social Marista - CESMAR), situated in Porto Alegre $(\mathrm{RG})$, is concerned with humanitarian questions and seeks to promote familiar inclusion and integration by creating self-esteem in the students coming from low-income communities. Its activities include lessons and workshops in support of the formal education. The Center also provides assistance to the community by helping to legalize their dwellings, a problem they have with the local authorities, and promotes workshops with the intent to establish income-creating groups based on the idea that in families without any income there can be no peace. The Center runs cooperatives (involving activities such as bakery, weaving and sewing), all of them created by the program as a means for reducing violence.

The greater part of these experiences acts in primary prevention, more specifically in the training of professionals for dealing with the different forms of violence, for establishing a proper relation to the people and their environment 13 , and for modifying the common sense with respect to violence and its different expressions. Three experiences operate on the secondary, preventive level. They try to prevent offending and discriminative behavior, drug abuse, involvement in criminal activities and drug dealing through early diagnosis and intervention ${ }^{13}$, and promote individualized assistance aimed at creating self-esteem and opportunity for better integration and social reinclusion of the children and adolescents attended by the programs. Only one of the investigated experiences promotes third-degree prevention, by means of multidisciplinary assistance to victims of sexual abuse and exploitation.

The main forum used in the preventive activities is, in eight out of nine cases, education by means of workshops and courses. Only one experience chose the traditional school environment for its preventive activities.

The diversity of attempts is characterized by actions in the following fields: 1) family focused successfully in three experiences. The fourth experience seeks to work in cooperation with the family, but the attempt did not produce results until the moment of this investigation; 2) work - focused by four of them through promotion of professionalizing courses, cooperation with companies and income-generating groups for the parents; 3 ) media - approach chosen by three experiences, using community therapy and popular mobilization.

The main actions developed by all of them are: distribution of educative material about protection against and prevention of violence, and organization of groups of adolescents, as can be seen in graph 1 .

In 2003, a total of 14,456 individuals were attended in all studied experiences (Graph 2).

\section{Graph 1}

Number of provided services per successful experience in the prevention of violence $-2003 / 2004$.

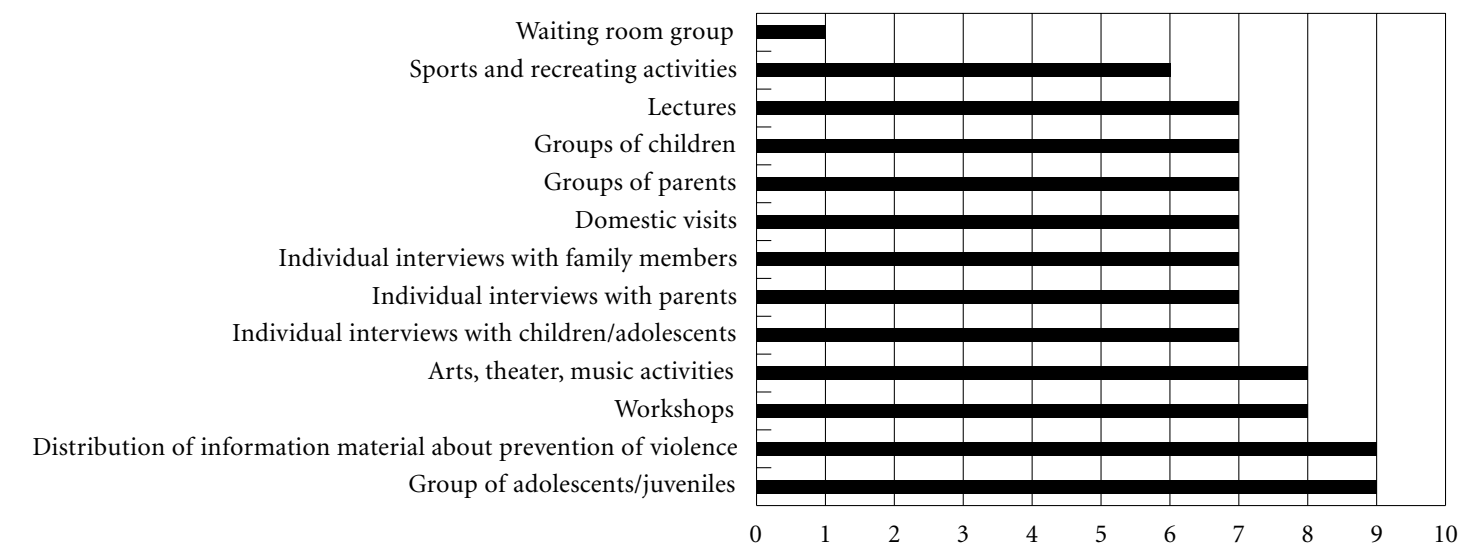


Graph 2

Number of services provided by successful experiences in the prevention of violence - 2003/2004.

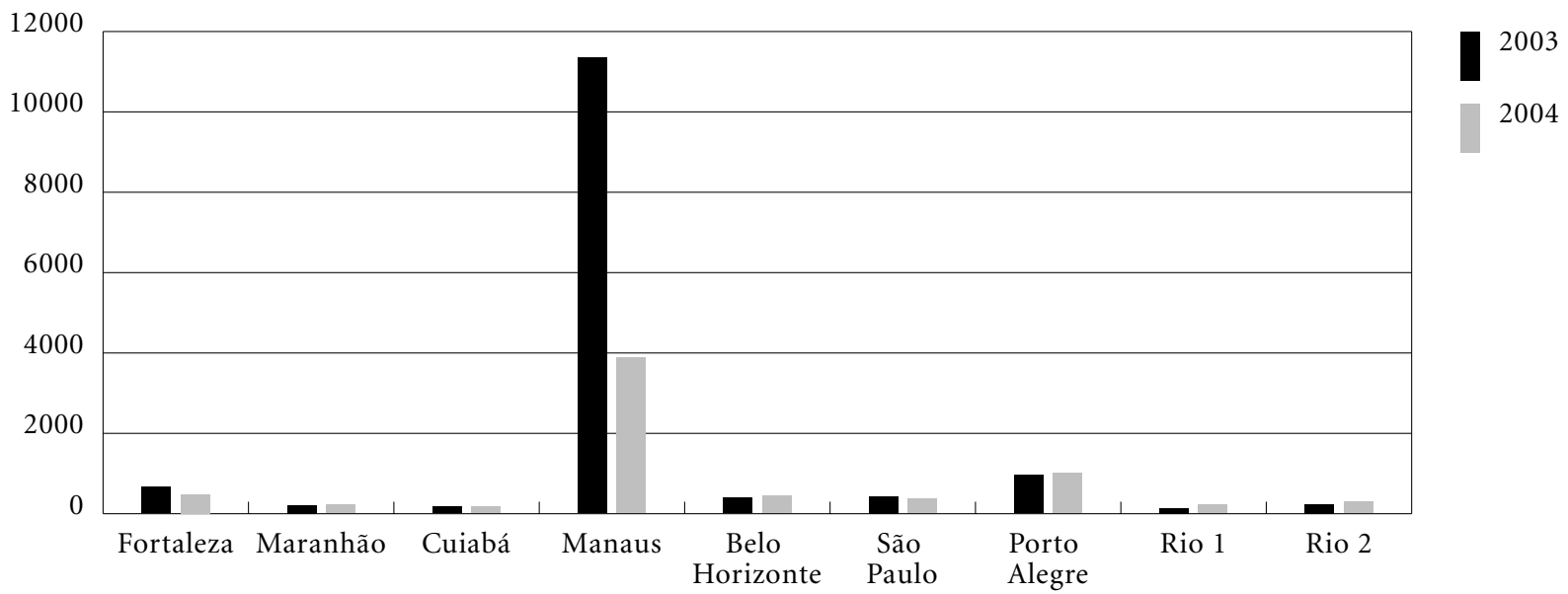

From this total, 11,337 individuals were approached by the NGO working with communication, a privileged position in comparison to the others, although, as can be seen, also subject to oscillations due to lack of funds. Excluding this program, a medium number of 390 individuals were attended per year/experience, varying between 124 attended by the NGO offering sports, and 950 by the experience focused on education and community services. In 2004, the total number of attended individuals in all studied cases was 7,004, showing the difficulties already mentioned in sustaining the services. This year, the NGO working with communication stands out with 3,565 attended individuals. The other experiences worked with a mean of 392 persons, similar to the year before. The highest and lowest number of participants, 1,000 and 210, during the school year, was maintained by the same NGOs.

As to the age groups attended in 2003 and 2004, we see that the institutions focus mainly children and adolescents between 10 and 19 years with preventive and protective actions, followed by the group between 7 and 11 years. Six experiences work with young adults between 20 and 24 years of age.

In 2003 and 2004, two institutions worked mainly with individuals of masculine sex, those mainly dedicated to sports and black culture.
The others gave priority to girls. One acted uniformly in both groups.

The results presented by the responsible for the experiences can be seen in graph 3. Increase of self-esteem in the young is the item emphasized by most institutions, followed by social reinclusion and decrease of child labor.

\section{Success and limitations in the prevention of violence seen from the viewpoint of the studied experiences}

The analysis of experiences considered fruitful shows the success achieved during a certain period, the process used and also the limitations met in their implementation.

Informed citizenship was one of the greatest achievements pointed out by managers, technicians and users of the nine experiences. According to Araújo ${ }^{14}$ and Njaine \& Souza ${ }^{15}$, the access to and use of information play a vital role in the construction of citizenship or civic practices, seeing that the conquest of political rights and implementation of duties depend on the availability of this symbolic good called information. The managers and users of the experiences used certain expressions for referring to the sense of their actions. The main expression was information about rights and $d u$ ties. Managers, technicians and users involved 
Graph 3

Results of preventive actions carried out by the successful experiences $-2003 / 2004$.

Reduces the possibility of drug consume by children/adolescents/juveniles

Prevents violence at schoo

Reduces the possibility of involvement of children/adolescents/juveniles in drug dealing

Promotes a culture of peace among children/adolescents/juveniles

Prevents domestic violence

Prevents infanto-juvenile sexual exploitation

Prevents violence among children/adolescents/juveniles

Prevents child labor

Promotes social inclusion of children/adolescents/juveniles

Promotes increase of self-esteem in children/adolescents/juveniles

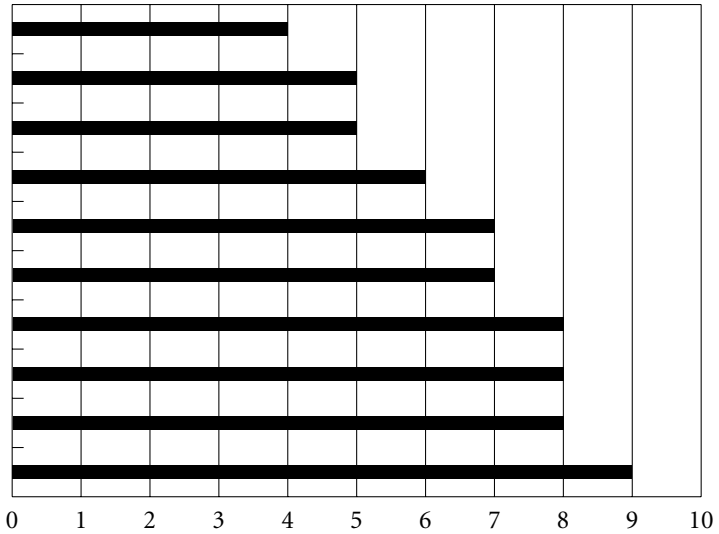

in the process agreed that this knowledge contributes to the internalization of reference values such as autonomy, freedom and growth of civic conscience. The statements emphasize the importance of knowing one's rights and duties as the basis for human relations and equality. This is in fact the core of the prevention of violence, knowing that violence means exactly not to recognize one's neighbor on an equal level. In this sense, the mentioned experiences were successful. The users consider themselves more informed about their rights, more enabled to prevent their violation.

Know how to deal with different people was another idea introduced to the concept of citizenship. With the words of an adolescent, who participated in the experience Building Peace in Rio de Janeiro: I learned how to deal with different people when I had a homosexual colleague and I also learned not to underestimate young people with physical differences because he never had imagined how intelligent they can be. Another adolescent participating in the Sentinel Program also observes that he learned to accept people the way they are [...], to deal with different people. These statements show the success of the informative work about how to deal with the different.

Specifically in relation to the Center of Black Culture (MA), managers and technicians emphasize the results obtained in promoting information about citizenship. We promote information so that children, adolescents and juve- niles, real or potential victims of violence, can participate in representative spaces, make part of movements for the defense human rights. This success pointed out by managers and technicians is very well illustrated in the statement of one of the adolescents participating in the Committee for the Defense of the Rights of the Black Population, which promotes actions against racial discrimination: I also participate in militancy, I am in this fight [against racial discrimination].

The international literature mentions the efficiency of activities focusing information about civic rights and duties, among other North American programs, which are visiting families and provide information to parents for motivating them to claim public services 16 . Sherman et al. 5 also consider information a relevant strategy in the prevention of violence, extending this context to other environments. The literature also suggests information in the family environment as an instrument for raising consciousness of the need to seek social support and as a tool for transforming relations; at school, information is pointed out as crucial for the development of individual and social abilities and competences; the community is emphasized as the main space where information should be motivated, stimulating the implantation of support networks and interaction of community movements.

Work preparation was another action considered successful in the process of preventing 
violence, expressed mainly in the testimonies of the managers, technicians and users of the experiences Social Center Marista (RS), Center for Black Culture (MA) and Fight for Peace $(\mathrm{RJ})$. Since Marx ${ }^{17}$, as well as in the understanding of recent authors like Dubar ${ }^{18}$, work occupies an eminent place in personal and social life. Marx said that the human being, on working, transforms nature and, by doing that, transforms itself. Besides the aspects of individual and social survival, Dubar focuses work as a reference for creating individual identity. Privation of work, above all of the socially recognized kind vesting the individual with a position in society and in its existential world, brings intimate suffering, affects self-esteem and personal identity and creates social disorganization.

The first reaction of the young people, who participate in the work preparation activities, is based on negation. Work is seen as a kind of shield against some possible misdirection. It is thus necessary to think about the conditions and possibilities these young people of the lower classes find in the labor market and about the positive sense they find in the occupations available to them in relation to the sense of their life. The first topic standing out in this connection is the real possibility of being less socially excluded. According to an adolescent participating in the Center for Black Culture (MA), there are activities, which are not taught in his school, activities that would "prepare the young for life and for facing the labor market".

Another sense given to work preparation is "to avoid exploitation in activities considered unlawful by the society". As an adolescent participating in the experience Fight for Peace (RJ) says: "Integrating the young in the society is also against drugs."

Work preparation is also seen as "a form of keeping the young away from a life in the streets or from delinquency". According to a participant of the experience Fight for Peace (RJ), the experience "gives the opportunity to work and [helps them] not to get involved with armed violence".

The managers and technicians of the Center for Black Culture (MA) and the Movement for Mental Health (CE) observe that work preparation should go hand in hand with formal education. Thus, work preparation should either coexist with this education or occur after the conclusion of elementary school education.
Studies showed that there is no direct automatic relation between labor opportunities/ employment and crime and violence 5, 6, 10. Not all Brazilian programs directed to work preparation are aimed at detention of violence but at the containment of risk factors like unemployment and social exclusion. For this reason, these programs, although directly aimed at reducing the rates of violence, represent the conquest of citizenship of the poorer population, deprived of social goods, and a way to promote quality of life.

Involvement of children and adolescents in recreating and educative activities was another activity considered successful, mainly by the managers and technicians of the experiences Center for Black Culture (MA), Circus for All (MG), Fight for Peace (RJ) and Movement for Mental Health (CE). Recreating activities involve, as observed by Brougère ${ }^{19}$, a certain culture of introjection and subjectivation of rules originated in the social environment. The idea of recreation as a game based on rules was also extensively studied by Piaget 20 . According to this author, socialized game not only adopts collective rules but also adapts symbolic imagination to reality.

We mentioned different types of activities in the prevention of violence, for example dance, theater, traditional games, sports and circus activities. The main idea of the playful activities is to live a better life and the idea of channeling aggressiveness. According to a manager making part of the experience Fight for Peace (RJ) "sports are today taking a position in their (the young) lives, they substitute violence by sports". One adolescent participating in the experience Circus for All (MG) mentioned that through these activities he "receives his childhood back". These words transmit the idea that these adolescents did not have the opportunity to play during their childhood and that they are doing it now.

There are references in the literature relating the success of recreating activities in the prevention of violence. Sherman et al. 5 consider recreating activities after school promising when properly guided and supervised, and Abramovay 21 mentions successful activities involving recreating activities open to students and their families in schools, during the weekends.

Gonçalves \& Sposito 22 , analyzing actions for preventing violence in schools, promoted by public institutions in São Paulo, also emphasize 
the success of an experience using recreating activities, sports and games. The program practically consists in a school, opening its doors during weekends for a variety of activities. According to the authors, the difficulties met in implementing this idea notwithstanding, these activities contributed to "reducing the violence rate observed before in this school" 22 .

The improvement of self-esteem is another success present in the testimonies, mainly of the managers of the experiences Center for Black Culture (MA), Social Center Marista (RS), Center for Victims of Violence, of the Institute Sedes Sapientiae (SP), and Movement for Mental Health (CE). Two principal senses were given to the promotion of self-esteem. The first one refers to promotion of stimuli that make children, young and adults like themselves, by becoming aware of their possibilities and limitations. For the manager of the Social Center Marista (RS), to work with "the question of self-esteem [makes the young] see themselves more as a person, as somebody of value, somebody who has possibilities". The work with the self-esteem of persons makes them "respect the life of others".

In the sense we dealt with them in the item before, activities directed to promote self-esteem lead to primary prevention of violence. By learning to "like oneself", persons do not feel victims, get used to deal with discriminations and physical and psychological aggressions, protect themselves and become stronger.

The other sense given by the interviewed managers to the work with self-esteem is related to a better capacity of dealing with life, above all in violent situations. Persons who were subject to violent situations are motivated to give a new meaning to their negative experiences, to train their capacities 23,24 in order not to be victimized again.

Here is an emotional testimony of a woman, who participates in the experience Center for Victims of Violence (SP), which works with parents, children and adolescents involved in domestic violence. According to this woman, she and her son succeeded in giving a new sense to their lives and to open new horizons: He was a person completely depressed. I could not speak, you know, I couldn't see things. It helped me a lot, it helped my boy. He learned to defend himself from his father. If I had not come here looking for a bit of safety and help, my life would not have sense anymore, my son wouldn't have command or dominion about himself.
The discussion about the relevance of working with self-esteem is supported by studies carried out in different countries. Most of them emphasize the good results obtained through preventive actions focusing the emotional and social competence of students, development of abilities, self-control, personal relations and reduction of conflicts6, 25, 26 .

An important chapter in this analysis of experiences, and the second goal of this article, was the identification of limits and difficulties met by the institutions. The first one is the difficulty to raise funds for ensuring the sustainability, continuity or sometimes an amplification of successful actions. The second one, revealing the practice and the organizational directives, refers to the lack of articulation with other groups or institutions. These two limitations are present in the testimonies of managers and technicians of the greater part of the studied experiences.

The difficulties in sustaining the projects $f i$ nancially were observed even in the case of experiences having fund-raising mechanisms. But in this specific case, the difficulties of the NGOs are different from those of the public institutions. Belonging to the "third sector", NGOs are private, voluntary, nonprofit initiatives dedicated to common welfare 27 . Their functioning depends on public funds or private donations, generally without any binding promise with respect to future support. On the other hand, the multiplication of NGOs was not followed by systematic evaluations, a fact causing uncertainty in the donors as refers to the application of the donated funds.

Some researchers, like Santos \& Avritzer 28, consider the "third sector" the less evaluated of the three that compose the democratic macroinstitutions (state-market-civil society). This fact, along with the voluntary character of many social initiatives, makes them financially completely vulnerable even when their activities are evaluated positively, principally by the users.

The testimony of different interviewed persons, managers, technicians and users, in the case of the NGOs, emphasize how much they feel unsafe with respect to the possibility of lack of funds for future actions. They are almost unisonous in saying: the survival of the experience depends on public funds, and these funds are not always available at time or to the extent necessary for meeting the demands. Many of the interviewed professionals are aware 
that they are taking over activities that should be developed by the state. Some NGOs count on a number of donors of different kinds, in part reducing their dependence from the state.

The testimonies of coordinators and technicians of public and private experiences reveal other problems. Although sustained by institutions, the activities of the experiences represent a kind of appendix, due to financial restrictions and insufficiencies, unable to achieve the dimension they could achieve.

From the viewpoint of the interviewed managers and technicians, the insufficiency of funds for developing the experiences results mainly in a lack of qualified personal for meeting the demand. In terms of quantity, there are too few professionals and they are not well paid. In terms of quality, the teams are not sufficiently qualified for dealing with the variety of activities and the different segments of society attended by the experiences.

The lack of articulation with other groups and institutions refers to the difficulty of articulating the different efforts for introducing the juveniles into the labor market. The testimony of an adolescent participating in the experience Center for Black Culture (MA) illustrates this problem: We have the qualification, all this preparation, all this practical and theoretical thing, but there is no agreement granting us a job.

Obviously, the fact of this adolescent being unable to enter the labor market cannot be explained only by the lack of adequate articulation between the studied experiences and the local companies. According to Segnini29, the structure of the labor market is influenced by the fact that "unemployment is no more the result of a lack of economic growth, it became an inherent part of economic growth", the advance of Brazilian capitalism is expressed significantly by "profound productive heterogeneity and inequality of the labor relations". It is however fundamental to emphasize this difficulty because it possibly reveals a lack of investment in the future perspectives of the young participants, in the pragmatic aspects they yearn.

Lack of articulation with the families was also named as a difficulty for the experiences with children and adolescents showing positive results. The testimony of a professional working in the experience Circus for All (MG) illustrates this question: There is still a great difficulty with the families, the work with the fami- lies is still in its beginning, but we are looking for partnership.

Studies carried out by the United Nations Children's Fund (UNICEF) and by CLAVES30 found that even for programs directed to prevention of violence against children and adolescents, involving the families, the transformation of the families from users into partners is a great challenge. According to this study, the programs including the family in the prevention of violence require amplification and articulation of the supporting network to be able to become a system for granting the rights of the child and the adolescent ${ }^{30}$.

We conclude that the studied experiences showed more success than limitations. The difficulties met by all of them, however, are no hindrance to their actions. On the contrary, they are seen as a challenge for continuing, expanding and improving.

\section{Final considerations}

The experiences analyzed in a field study can be considered successful as refers to some actions traditionally efficient in the prevention of violence against children and adolescents. The testimonies of users report increased self-esteem, better preparation for entering the labor market, improved awareness of their civic rights and duties, and investment of time and energy in educative and recreating activities.

A comparison of the success achieved in the studied national experiences for prevention of violence against children and adolescents and the international literature shows common aspects. Sherman et al. 5 , for example, analyzing more than 500 North American programs, established the following indicators for success: reduced involvement in infractions and violence; less alcohol and drug abuse; less victimization; reduction of antisocial, offending behavior and less disrespect to social rules; return to school and better educational level; inclusion in the labor market. On individual level: increased social competence, self-control, strengthening of moral values and critical awareness and care in the relation with others and with oneself.

Articulating the studied Brazilian experiences with the North American ones, one notes syntony of some results: work preparation, promotion of self-esteem and self-knowledge, the increasing involvement of children and 
adolescents in formal education. However, it has to be emphasized that the international studies are focused primarily on a quantitative assessment of the results related by the experiments. In Brazil, social programs use to be scarcely documented in terms of statistics. Epidemiological evaluations of such extent are therefore impossible.

Thus, it is necessary to develop specific indicators for evaluating the quality of services dedicated to prevention of violence, a very recent practice in Brazil. Even on international level one does not find much with respect to qualitative indicators. In general, the evaluations assess the kinds of services and concrete results based on quantitative indicators.

The investigation underlying this article still emphasizes as problematic points of the experiences the lack of systematic institutional records and evaluations. As a result, there are no quantitative and qualitative parameters available for indicating impact in the decrease of violence.

From the viewpoint of the limitations, all experiences engaged in actions involving the families emphasize the need of investment, mainly because the greater part of these institutions is working with the low-income population. Any operation dedicated to this group must understand and take into consideration the difficulties these families are facing for being able to convince them to participate in the actions typically promoted by these experiences.

Financial instability or lack of funds is another point calling for attention. The interruption of activities does not only harm the efforts of an institution. It causes harm to those who participate in the experiences and count on the social support provided by these programs. On the other hand, the origin of these experiences is contradictory in itself: the organizations engaged in these activities are nonprofit entities, created exactly because the public authorities did not do the job. Thus, as voluntary initiatives, the survival of these experiences will probably always be problematic.

The studied experiences - although not the only successful in the country but just a conveniently selected sample - point to the consolidation of concrete and innovating forms of action towards prevention of violence, with emphasis to social inclusion. For this reason, these experiences need to be published, supported and incorporated into the collection of public policies, no matter in which sector - health, education, public security, media or culture.

On the other hand, it is necessary to assess more experiences engaged in prevention of violence to enable us to refine indicators for results and to compare success and limitations on national and international level.

The fragmentation of many actions in the prevention of violence today being conducted in the country obliterate the success achieved individually by some of them, isolates the possibility of sharing the financial, human, material and social resources necessary for the preventive activities. The dichotomies existing between public and private initiatives, the "third sector" and the different forms of action of each profession need to be overcome gradually. The constant interruptions in the support to professionals and efforts hamper and disarticulate important actions. Who pays the price is society. Those however, who use these services, who give support to the social engagement of the involved professionals, those who try to overcome difficulties day by day, are moved by the hope for a future of informed citizenship and social inclusion for many, many vulnerable children and adolescents.

\section{Collaborations}

R Gomes, MCS Minayo, SG Assis, K Njaine and M Sheinker have contributed equally during the manuscript preparation 


\section{References}

1. Minayo MCS, Fraga PCP, Assis SG, Souza ER, Deslandes SF, Njaine K, et al. Políticas sociais para jovens no Rio de Janeiro: cadastro e análise de casos. Rio de Janeiro: Ed. Fiocruz; 1999.

2. Minayo MCS, Souza ER. É possível prevenir a violência? Reflexões a partir do campo da Saúde Pública. Rev C S Col 1999; 4(1):7-32.

3. Banco Mundial. Prevenção comunitária do crime e da violência em áreas urbanas da América Latina: um guia de recursos para municípios. São Paulo: Banco Mundial; 2003

4. Nuttal C, Goldblatt P, Lewis C. Reducing offending: an assessment of research on ways of dealing with of fending behavior. London: Home Office; 1998.

5. Sherman LW, Gottfredson D, MacKenzie D, Eck J, Reuter P, Bushway S. Prevention crime: what works, what doesn't, what's promising: a report to the United States Congress. Washington, DC: National Institute of Justice; 1997.

6. Thornton TN, Craft CA, Dahlberg LL, Lynch BS, Baer $\mathrm{K}$. Best practices of youth violence prevention: a sourcebook for community action. Atlanta: Centers for Disease Control and Prevention/National Center for Injury Prevention and Control/Division of Violence Prevention; 2002.

7. Becker HS. Método de pesquisa em ciências sociais. São Paulo: Hucitec; 1993.

8. Denzin N K. The research act. Chicago: Aldine Publishing Company; 1973.

9. Minayo MCS. Conceito de avaliação por triangulação de métodos. In: Minayo MCS, Assis SG, Souza ER, organizadores. Avaliação por triangulação de métodos: abordagem de programas sociais. Rio de Janeiro: Ed. Fiocruz; 2005. p. 19-51.

10. Mesquita Neto P, Assis SG, Chasin ACM, Daher M, Ricardo CM. Relatório sobre a prevenção do crime e da violência e a promoção da segurança pública no Brasil. Rio de Janeiro: Secretaria Nacional de Segurança Pública (SNASP), Programa das Nações Unidas para o Desenvolvimento (PNUD), Federação das Indústrias do Rio de Janeiro (Firjan); Brasília: Ministério da Justiça/Projeto Arquitetura Institucional do Sistema Único de Segurança Pública; 2004. [Mimeo.]

11. Gomes R, Souza ER, Minayo MCS, Silva CFR. Organização, processamento, análise e interpretação de dados: o desafio da triangulação. In: Minayo MCS, Assis SG, Souza ER, organizadoras. Avaliação por triangulação de métodos: abordagem de programas sociais. Rio de Janeiro: Ed. Fiocruz; 2005. p. 185-221.

12. Assis DG, Deslandes SF, Minayo MCS, Santos NC. Definição de objetivos e construção de indicadores visando a triangulação. In: Minayo MCS, Assis SG, Souza ER, organizadoras. Avaliação por triangulação de métodos: abordagem de programas sociais. Rio de Janeiro: Ed. Fiocruz; 2005. p. 105-32.

13. Gomes R, Silva CMFP, Njaine K. Prevenção à violência contra a criança e o adolescente sob a ótica da saúde: um estudo bibliográfico. Rev C S Col 1999; 4(1): 171-81
14. Araújo EA. Informação, sociedade e cidadania: gestão da informação no contexto de organizações nãogovernamentais (ONGs) brasileiras. Ci Inf 1999; $8(2): 155-67$.

15. Njaine K, Souza ER. Informação e comunicação sobre violência: instrumentos para a cidadania. In: Minayo MCS, Souza ER organizadores. Violência sobre o olhar da saúde: a infrapolítica da contemporaneidade brasileira. Rio de Janeiro: Ed. Fiocruz; 2003. p. 269-282.

16. Bilukha O, Hahn RA, Crosby A, Fullilove MT, Liberman A, Moscicki E, et al. The effectiveness of early childhood home visitation in preventing violence: a systematic review. Am J Prev Med 2005; 28(2 Suppl 1): 11-39.

17. Marx K. O capital. Livro 1, cap. 6 [inédito]. São Paulo: Ciências Humanas; 1978.

18. Dubar C. A socialização: construção das identidades sociais e profissionais. São Paulo: Martins Fontes; 2005.

19. Brougère G. A criança e a cultura lúdica. In: Kishimoto I, organizador. O brincar e suas teorias. São Paulo: Thomson Pioneira; 2002. p. 19-32.

20. Piaget J. A formação do símbolo na criança: imitação, jogo e sonho, imagem e representação. Rio de Janeiro: Zahar; Brasília: INL; 1975.

21. Abramovay M. Escolas inovadoras: experiências bemsucedidas em escolas públicas. Brasília: Unesco; 2003.

22. Gonçalves LAO, Sposito MP. Iniciativas públicas de redução da violência escolar no Brasil. Cad Pesqui 2002; 115:101-38.

23. Assis SG, Avanci JQ. Labirinto de espelhos: a formação da auto-estima na infância e adolescência. Rio de Janeiro: Ed. Fiocruz; 2004

24. Rosenberg M. Society and the adolescent self-image. Princeton, NJ: Princeton University Press; 1989.

25. Krug EG, Dahlberg LL, Mercy JA, Zwi AB e Lozano $\mathrm{R}$, editores. Relatório mundial sobre violência e saúde. Genebra: Organização Mundial de Saúde; 2002.

26. Negreiros J. Delinqüências juvenis: trajectórias, intervenções e prevenção. Lisboa: Notícias Editorial; 2001.

27. Madeira FR, Biancardi MR. O desafio das estatísticas do terceiro setor. São Paulo em Perspectiva 2003; 17 (3-4):177-84

28. Santos BS, Avritzer L. Para ampliar o cânone democrático. In: Santos BS, organizador. Democratizar a democracia: os caminhos da democracia participativa. Rio de Janeiro: Civilização Brasileira; 2002. p. 39-82.

29. Segnini LRP. Educação e trabalho: uma relação tão necessária quanto insuficiente. São Paulo em Perspectiva $2000 ; 14(2): 72-81$.

30. Deslandes SF, Assis SG, Njaine K, Ximenes LF, Gomes R, Cabral CA, et al. Famílias: parceiras ou usuárias eventuais? Análise de serviços de atenção a famílias com dinâmica de violência doméstica contra crianças e adolescentes. Brasília: Claves/ENSP/Fiocruz, Unicef; 2004

Article presented in 3/03/2006

Approved in 15/03/2006

Final version presented in 26/04/2006 